\title{
Antibacterial activity of pomegranate fruit peels and arils
}

\author{
Tianchai Nuamsetti, Petlada Dechayuenyong, Sukon Tantipaibulvut* \\ Department of Microbiology, Faculty of Science, King Mongkut's University of Technology Thonburi, \\ 126 Pracha-Uthit Road, Bangmod, Tungkru, Bangkok 10140 Thailand \\ ${ }^{*}$ Corresponding author, e-mail: sukon.tan@ $@$ kmutt.ac.th
}

Received $7 \mathrm{Feb} 2012$

Accepted 9 Aug 2012

\begin{abstract}
The in vitro antibacterial activities of different extracts of pomegranate fruit peels and arils (with seeds) were investigated by agar-well diffusion and broth dilution methods against four food-related bacteria (Bacillus subtilis, Staphylococcus aureus, Escherichia coli, and Salmonella typhimurium). The solvents used as extractants in this study were hot water, $95 \%$ ethanol, and acetone. Their total phenolic contents were also evaluated. All pomegranate extracts contained high levels of phenolics and exhibited antibacterial activity against all bacteria tested. The hot-water extract of the peels was the most potent with the minimal inhibitory concentration of $207 \mathrm{mg} / \mathrm{ml}$ against E. coli and less than $103.6 \mathrm{mg} / \mathrm{ml} \mathrm{against}$ the other bacteria. Gram-positive bacteria were generally more sensitive to the extracts than Gram-negative ones.
\end{abstract}

KEYWORDS: minimal inhibitory concentration (MIC), Gram positive bacteria, Gram negative bacteria, total phenolic content

\section{INTRODUCTION}

Pomegranate (Punica granatum L.) fruits are widely consumed, fresh and in commercial products, such as juices, jams, and wines. Most pomegranate fruit parts are known to possess substantial antioxidant activity ${ }^{1}$. The flower ${ }^{1}$, seed oil ${ }^{2}$, seed extract, and peel extract ${ }^{3}$ of pomegranate also have a potent antioxidant activity. Furthermore, the water-methanol extract of pomegranate peel possesses antimicrobial activity against eleven microorganisms, such as Bacillus subtilis, Staphylococcus aureus, Yersinia enterocolitica, Listeria monocytogenes, Candida utilis, Saccharomyces cerevisiae, and Aspergillus niger ${ }^{4}$. Braga et $\mathrm{al}^{5}$ reported that the methanol extracts of $P$. granatum whole fruits were able to inhibit not only the growth of $S$. aureus FRI 722 but also the production of enterotoxins. However, rare studies have reported antibacterial activity of pomegranate arils. In this study, we examined the antibacterial activity of hotwater extract, ethanol extract, and acetone extract of pomegranate fruit peels and arils (with seeds) by agar-well diffusion and broth-dilution method against four food-related bacteria- two Gram-positive bacteria (B. subtilis and S. aureus) and two Gram-negative bacteria (E. coli and S. typhimurium).

\section{MATERIALS AND METHODS}

\section{Pomegranate fruit and preparation of the extracts}

Pomegranate fruits were purchased from local markets in Bangkok. After opening the fruit, the arils (with seeds) were manually separated from the peels. Collected peels and arils were then rinsed with tap water. These peels and arils were ground separately in a blender. Fifty grams of blended peels or arils were placed in 250-ml Erlenmeyer flasks, followed by adding $100 \mathrm{ml}$ of solvents having an increasing polarity: acetone, $95 \%$ ethanol, and hot water. The flasks were then shaken at room temperature for $18 \mathrm{~h}$ prior to filtration. The filtrates were concentrated under reduced pressure with a rotary evaporator at $40{ }^{\circ} \mathrm{C}$. These crude extracts were kept at $4{ }^{\circ} \mathrm{C}$ until use.

\section{Microorganisms and culture}

A total of four food-related bacteria were kindly provided by the Culture Collection of Department of Microbiology, Faculty of Science, King Mongkut's University of Technology Thonburi. They are two Grampositive bacteria (B. subtilis and S. aureus) and two Gram-negative bacteria (E. coli and S. typhimurium). The strains were maintained at $4{ }^{\circ} \mathrm{C}$ in Mueller Hinton agar slants. Before experimental use, cultures from solid media were sub-cultivated in Mueller Hinton broth, incubated for $24 \mathrm{~h}$ at $37^{\circ} \mathrm{C}$, and used as the inocula for the determination of antibacterial activity.

\section{Determination of antibacterial activity}

The modified agar well-diffusion method ${ }^{6}$ was conducted to evaluate the antibacterial activities of the extracts. A freshly grown culture was serially diluted, and $0.1 \mathrm{ml}$ of prepared cells $\left(1.5 \times 10^{7}\right.$ colony forming 
units per millilitre, $\mathrm{CFU} / \mathrm{ml}$ ) was aseptically spread onto the surface of Mueller Hinton agar and then left to dry for $30 \mathrm{~min}$. Wells $(8 \mathrm{~mm}$ in diameter) were made in media using a sterilized stainless steel borer. Each well was filled with $30 \mu$ of the crude extracts. The plates were left at room temperature for $30 \mathrm{~min}$ to allow diffusion of materials in media. The controls were prepared using residue obtained by concentrating each solvent under reduced pressure (the same as done with the filtrates) and diluting with $10 \mathrm{ml}$ DMSO. Plates were incubated at $37^{\circ} \mathrm{C}$ for 18 $24 \mathrm{~h}$. Inhibition zones in mm (including well diameter) around wells were measured. The antibacterial activity was expressed as the diameter of inhibition zones produced by the extracts against test bacteria. All tests were performed in triplicate. The results were expressed as mean \pm standard deviation. Statistical significance was calculated by ANOVA, followed by Scheffé's test. The $p$ values of $<0.05$ were considered significant.

\section{Determination of MIC}

The broth-dilution method ${ }^{7}$ was adopted to determine the minimal inhibitory concentration (MIC) of the active extract revealed by the previous well assay. The inoculum of each test bacterium was prepared by diluting the overnight culture of the bacterium in Mueller Hinton broth to a level of $1.5 \times 10^{7} \mathrm{CFU} / \mathrm{ml}$. Two millilitres of the extracts diluted in two-fold dilution with DMSO were added to a sterile glass tube containing $0.5 \mathrm{ml}$ Mueller Hinton broth (the concentration of bacteria approximately $1.5 \times 10^{7} \mathrm{CFU} / \mathrm{ml}$ ). The tubes were incubated at $37^{\circ} \mathrm{C}$ for $18-24 \mathrm{~h}$. Because of the turbidity and dark colour of the extracts, $0.1 \mathrm{ml}$ of the mixture in the tubes were spread onto the surface of Mueller Hinton agar. Plates were incubated at $37^{\circ} \mathrm{C}$ for $18-24 \mathrm{~h}$. The MIC was defined as the lowest concentration $(\mathrm{mg} / \mathrm{ml})$ of the extract resulting in bacteria density lower than 300 colonies per plate. The test was conducted twice.

\section{Determination of total phenolic content}

The total phenolic content of all extracts was determined using the Folin-Ciocalteu method described previously ${ }^{8}$. Briefly, $0.5 \mathrm{ml}$ of diluted extract was added to a test tube and then mixed with $5 \mathrm{ml}$ of Folin-Ciocalteu reagent $(0.2 \mathrm{~N})$. After $8 \mathrm{~min}, 2 \mathrm{ml}$ of $\mathrm{Na}_{2} \mathrm{CO}_{3}(15 \%)$ was added. The reaction mixture was incubated at $50{ }^{\circ} \mathrm{C}$ for $15 \mathrm{~min}$ before the absorbance (at $760 \mathrm{~nm}$ ) of mixtures was recorded against a blank. Total phenolic content of the extracts was calculated from standard gallic acid solutions $(0-0.1 \mathrm{mg} / \mathrm{ml})$, and expressed as mg gallic acid equivalents (GAE) per $100 \mathrm{~g}$ fruit dry weight.

The 100-g fruit dry-weight was calculated from the quantity $(\mathrm{ml})$ of each extract obtained from $50 \mathrm{~g}$ of either blended peels or arils (with seeds). Other representative pomegranate fruit peels or arils were weighed, dried for $18 \mathrm{~h}$ at $95^{\circ} \mathrm{C}$, and the dry masses were recorded. If $X \mathrm{ml}$ of the extract was obtained from $50 \mathrm{~g}$ of peels or arils, and $Y \mathrm{~g}$ of dry masses was obtained from $Z \mathrm{~g}$ of peel or aril wet weight, then the dry weight of $0.5 \mathrm{ml}$ extract (in grams) equals

$$
\frac{(50 \mathrm{~g})(0.5 \mathrm{ml})(Y \mathrm{~g})}{(Z \mathrm{~g})(X \mathrm{ml})} .
$$

If $0.5 \mathrm{ml}$ extract has $V \mathrm{mg}$ GAE of total phenolic contents, this equals

$$
\frac{(V \mathrm{mg} \mathrm{GAE})(100 \mathrm{~g})(Z \mathrm{~g})(X \mathrm{ml})}{(50 \mathrm{~g})(0.5 \mathrm{ml})(Y \mathrm{~g})}
$$

(in mg GAE per $100 \mathrm{~g}$ fruit dry weight).

\section{RESULTS AND DISCUSSION}

Four food-related bacteria were tested for their sensitivity to hot-water extract, ethanol extract, and acetone extract of pomegranate fruit peels and arils (with seeds). The antibacterial potency was initially determined by the agar well-diffusion method. Table 1 presents diameters of inhibition zones (clear zones around wells) exerted by the different extracts towards test bacteria. The solvent residue diluted with DMSO (the control) showed no inhibitory zone. On the other hand, all extracts from pomegranate fruit peels and arils exhibited inhibitory activity against all test bacteria (Table 1), with the highest inhibition zones on ethanol extracts (26.3-34.0 mm inhibition zones for peels and 19.7-24.3 mm inhibition zones for arils). The ethanol extracts of arils have significantly higher antibacterial activity than other aril-extracts. On the other hand, the antibacterial activity of ethanol extract of peels was not significantly different from other extracts of peels. Siri et $\mathrm{al}^{9}$ found that both water and ethanol extracts of pomegranate fruit peels showed anti-Aeromonas caviae activity with more effectiveness in water extracted samples. In contrast, Al-Zoreky ${ }^{4}$ reported that only water-methanol extract of peels have marked inhibition (12-20 mm inhibition zones) and the water extract was inactive against eleven microorganisms tested, such as S. aureus (2 strains), B. subtilis, E. coli, Listeria monocytogenes, Pseudomonas aeruginosa, Klebsiella pneumoniae, Yersinia enterocolitica, Candida utilis, Saccharomyces cerevisiae, and Aspergillus 
Table 1 Antibacterial activity of different extracts of pomegranate fruit peels and arils determined by agar well-diffusion method.

\begin{tabular}{|c|c|c|c|c|c|c|}
\hline \multirow[t]{3}{*}{ Microorganism } & \multicolumn{6}{|c|}{ Inhibition zone (mm) } \\
\hline & \multicolumn{2}{|c|}{ Hot water extract } & \multicolumn{2}{|c|}{ Ethanol extract } & \multicolumn{2}{|c|}{ Acetone extract } \\
\hline & Peel & Aril & Peel & Aril & Peel & Aril \\
\hline B. subtilis & $28.0 \pm 1.7^{\mathrm{a}}$ & $15.0 \pm 0.0^{\mathrm{x}}$ & $31.0 \pm 1.7^{\mathrm{a}}$ & $24.3 \pm 0.6^{y}$ & $31.0 \pm 1.0^{\mathrm{a}}$ & $14.3 \pm 1.2^{\mathrm{x}}$ \\
\hline S. aureus & $30.0 \pm 0.0^{\mathrm{a}}$ & $16.7 \pm 1.5^{\mathrm{x}}$ & $34.0 \pm 1.7^{\mathrm{b}}$ & $20.7 \pm 1.2^{\mathrm{y}}$ & $30.7 \pm 1.2^{\mathrm{a}}$ & $19.3 \pm 1.2^{\mathrm{x}, \mathrm{y}}$ \\
\hline E. coli & $27.0 \pm 1.0^{\mathrm{a}}$ & $14.0 \pm 1.0^{\mathrm{x}}$ & $29.0 \pm 1.0^{\mathrm{a}}$ & $23.7 \pm 0.6^{\mathrm{y}}$ & $30.3 \pm 0.6^{\mathrm{a}}$ & $15.7 \pm 1.2^{\mathrm{x}}$ \\
\hline S. typhimurium & $23.7 \pm 0.6^{\mathrm{a}}$ & $15.7 \pm 1.2^{\mathrm{x}}$ & $26.3 \pm 1.2^{\mathrm{b}}$ & $19.7 \pm 0.6^{\mathrm{x}}$ & $24.7 \pm 0.6^{\mathrm{a}, \mathrm{b}}$ & $17.0 \pm 2.6^{\mathrm{x}}$ \\
\hline
\end{tabular}

Means and standard deviation for $n=3$. For each bacteria, the experimental values within each row that have no common superscript are significantly different $(p<0.05)$ according to Scheffé's multiple comparison test. Any two means not marked by the same superscript (for example, a and b for the extracts of peels and $\mathrm{x}$ and $\mathrm{y}$ for the extracts of arils) are significantly different $(p<0.05)$. Any two means marked by the same superscript (for example, a and a or $\mathrm{x}$ and $\mathrm{x}$ ) are not significantly different.

niger. Meléndez and Capriles ${ }^{10}$ found that methanol extract of pomegranate fruit was active against $E$. coli, $S$. aureus, and B. subtilis with the diameter of inhibition zone 12,22 , and $12 \mathrm{~mm}$, respectively. The activity of ethanol extracts of peels against $S$. aureus, B. subtilis and E. coli (29-34 mm inhibition zones, Table 1) was comparable to the study of Ahmad and Beg $^{6}$ (10-40 $\mathrm{mm}$ inhibition zones), but higher than that of Al-Zoreky ${ }^{4}$ (13-17 mm inhibition zones). This may be due to the different extraction method, strain sensitivity, antimicrobial procedures used in the test. The extract seems to be thermostable because the hotwater extract (using boiling water) still retained the activity nearly the same as other extracts. This was also found by Al-Zoreky ${ }^{4}$.

Quantitative evaluation of antimicrobial activity of all extracts was carried out against test bacteria by broth dilution techniques. The MIC, in $\mathrm{mg} / \mathrm{ml}$, of all extracts is presented in Table 2. It appeared that the hot-water extract of the peels was the most effective against all test bacteria with the MIC values less than $210 \mathrm{mg} / \mathrm{ml}$ (Table 2). Moreover, the hot water extract of the arils was also effective against $B$. subtilis and $S$. typhimurium with the MIC value of $105 \mathrm{mg} / \mathrm{ml}$. This may relate to some components in the extract that dissolved well in the water but did not diffuse well through the agar. The opposite was found by Prashanth et al ${ }^{11}$ who reported that methanol extracts of peels were more active than water extracts against E. coli, S. aureus, and B. subtilis. The MIC of the methanol extracts was $6-12 \mathrm{mg} / \mathrm{ml}$, while that of the water extracts was $25-50 \mathrm{mg} / \mathrm{ml}$. In this study, the MIC for ethanol extract of peels was $242-500 \mathrm{mg} / \mathrm{ml}$ against all test bacteria (Table 2). Voravuthikunchai et $\mathrm{al}^{12}$ found that the aqueous extract of pomegranate peel was active against $E$. coli $\mathrm{O} 157: \mathrm{H} 7, \mathrm{MIC} / \mathrm{MBC}$
Table 2 Minimum inhibitory concentration (MIC) of different extracts of pomegranate fruit peels and arils determined by broth dilution method.

\begin{tabular}{|c|c|c|c|c|c|c|}
\hline \multirow[t]{3}{*}{ Microorganism } & \multicolumn{6}{|c|}{ MIC (mg/ml) } \\
\hline & \multicolumn{2}{|c|}{$\begin{array}{c}\text { Hot water } \\
\text { extract }\end{array}$} & \multicolumn{2}{|c|}{$\begin{array}{l}\text { Ethanol } \\
\text { extract }\end{array}$} & \multicolumn{2}{|c|}{$\begin{array}{c}\text { Acetone } \\
\text { extract }\end{array}$} \\
\hline & Peel & Aril & Peel & Aril & Peel & Aril \\
\hline B. subtilis & $<104$ & 105 & 242 & 194 & 444 & 222 \\
\hline S. aureus & $<104$ & 840 & 242 & 778 & 444 & 888 \\
\hline E. coli & 207 & 840 & 499 & 778 & 3500 & 888 \\
\hline S. typhimurium & $<104$ & 105 & 242 & 778 & $<222$ & 1776 \\
\hline
\end{tabular}

$0.19 / 0.39 \mathrm{mg} / \mathrm{ml}$. Variations in results among studies on pomegranate fruit peel extracts were recorded with MIC determination. The values for MIC against $S$. aureus ranged from 0.62 to $\geqslant 250 \mathrm{mg} / \mathrm{ml}^{4}$. The MIC varied from $0.39-25 \mathrm{mg} / \mathrm{ml}$ against several strains of E. $\operatorname{coli}^{4,11,12}$.

The MIC values for test bacteria seemed to correlate with the total phenolic content found in the extracts. The total phenolic content of hot-water extracts of fruit peels was the highest, followed by the ethanol and acetone extracts, respectively (Table 3). This showed that the solvent that is less polar (acetone) extracted less amount of total phenolic compounds. Polyphenols are hydrophilic phytochemicals and thus more hydrophilic extractants are better solvents for their recovery from plant ${ }^{4}$. Different results were found by Negi et al ${ }^{13}$ who used sun-dried and powdered pomegranate peels extracted with a Soxhlet extractor. They reported that the phenolic content of acetone, methanol, and water extracts of the peels was 52, 46.2, and 4.8\%, respectively. Pomegranate 
Table 3 Total phenolic content of different extracts of pomegranate fruit peels and arils.

\begin{tabular}{lccc}
\hline Pomegranate & \multicolumn{3}{c}{ Total phenolic content } \\
& \multicolumn{2}{c}{ (mg GAE/100 g dry weight) } \\
\cline { 2 - 4 } & $\begin{array}{c}\text { Hot water } \\
\text { extract }\end{array}$ & $\begin{array}{c}\text { Ethanol } \\
\text { extract }\end{array}$ & $\begin{array}{c}\text { Acetone } \\
\text { extract }\end{array}$ \\
\hline Peels & 166.83 & 152.65 & 85.48 \\
Arils (with seeds) & 87.32 & 72.84 & 64.60 \\
\hline
\end{tabular}

peel contains substantial amounts of polyphenols such as ellagic tannins, ellagic acid, and gallic acid ${ }^{13}$. Hayrapetyan et al ${ }^{14}$ found that two pure compounds commonly found in pomegranate-peel extract, namely ellagic acid and gallic acid, did not show considerable inhibition of L. monocytogenes. Ahmad and $\mathrm{Beg}^{6}$ reported that the phytochemical components found in alcoholic extract of pomegranate are alkaloid, flavonoid, glycoside, phenol, and tannin. Li et al ${ }^{15}$ reported that phenolic compounds in pomegranate juice are punicalagin isomers, ellagic acid derivatives, and anthocyanins. Machado et $\mathrm{al}^{16}$ reported the antibacterial activity of punicalagin against $S$. aureus (MRSA strains) with the MIC value of $768 \mu \mathrm{g} / \mathrm{ml}$.

\section{CONCLUSIONS}

Besides having high antioxidant activity, pomegranate arils also have antibacterial activity and may be used as medicine for humans. This reduces the cost and the risk of antibiotic consumption. Furthermore, addedvalue from the peels which is the byproduct could provide health benefits to humans and may be employed in food preservation and pharmaceutical purposes.

\section{REFERENCES}

1. Kaur G, Jabbar Z, Athar M, Alam MS (2006) Punica granatum (pomegranate) flower extract possesses potent antioxidant activity and abrogates Fe-NTA induced hepatotoxicity in mice. Food Chem Toxicol 44, 984-93.

2. Schubert SY, Lansky EP, Neeman I (1999) Antioxidant and eicosanoid enzyme inhibition properties of pomegranate seed oil and fermented juice flavonoids. J Ethnopharmacol 66, 11-7.

3. Singh RP, Chidambara Murthy KN, Jayaprakasha GK (2002) Studies on the antioxidant activity of pomegranate (Punica granatum) peel and seed extracts using in vitro models. $J$ Agr Food Chem 50, 81-6.

4. Al-Zoreky NS (2009) Antimicrobial activity of pomegranate (Punica granatum L.) fruit peels. Int $J$ Food Microbiol 134, 244-8.

5. Braga LC, Shupp JW, Cummings C, Jett M, Takahashi JA, Carmo LS, Chartone-Souza E, Nascimento AMA (2005) Pomegranate extract inhibits Staphylococcus aureus growth and subsequent enterotoxin production. J Ethnopharmacol 96, 335-9.

6. Ahmad I, Beg AZ (2001) Antimicrobial and phytochemical studies on 45 Indian medicinal plants against multi-drug resistant human pathogens. J Ethnopharmacol 74, 113-23.

7. Rodríguez Vaquero MJ, Tomassini Serravalle LR, Manca de Nadra MC, Strasser de Saad AM (2010) Antioxidant capacity and antibacterial activity of phenolic compounds from Argentinian herbs infusions. Food Contr 21, 779-85.

8. Chaovanalikit A, Mingmuang A (2007) Anthocyanin and total phenolic content of mangosteen and its juices. SWU Sci J 23, 68-78.

9. Siri S, Wadbua P, Wongphathanakul W, Kitancharoen N, Chantaranothai P (2008) Antibacterial and phytochemical studies of 20 Thai medicinal plants against catfish-infectious bacteria, Aeromonas caviae. KKU Sci J 36(Supplement), 1-10.

10. Meléndez PA, Capriles VA (2006) Antibacterial properties of tropical plants from Puerto Rico. Phytomedicine 13, 272-6.

11. Prashanth D, Asha M, Amit A (2001) Antibacterial activity of Punica granatum. Fitoterapia 72, 171-3.

12. Voravuthikunchai S, Lortheeranuwat A, Jeeju W, Sririrak T, Phongpaichit S, Supawita T (2004) Effective medicinal plants against enterohaemorrhagic Escherichia coli O157:H7. J Ethnopharmacol 94, 49-54.

13. Negi PS, Jayaprakasha GK, Jena BS (2003) Antioxidant and antimutagenic activities of pomegranate peel extracts. Food Chem 80, 393-7.

14. Hayrapetyan H, Hazeleger WC, Beumer RR (2012) Inhibition of Listeria monocytogenes by pomegranate (Punica granatum) peel extract in meat paté at different temperatures. Food Contr 23, 66-72.

15. Li Y, Guo C, Yang J, Wei J, Xu J, Cheng S (2006) Evaluation of antioxidant properties of pomegranate peel extract in comparison with pomegranate pulp extract. Food Chem 96, 254-60.

16. Machado TB, Leal ICR, Amaral ACF, Santos KRN, Silva MG, Kuster RM (2002) Antimicrobial ellagitannin of Punica granatum fruits. J Braz Chem Soc 13, 606-10. 